\title{
HIV-AIDS AND ISLAM' IN INDONESIA; POWER NARRATIVES AND RESISTANCE
}

\author{
Syamsu Madyan \\ Lecture Of Agama Islam Faculty \\ University of Islam Malang \\ Email : madyan981@gmail.com
}

\begin{abstract}
This paper can be identified as an AIDS anti-stigma related project, which orients its query to the particular problem of social stigma based on religion in Indonesia. It analyze how Islamic authorities and leadership in Indonesia has the power in the construction of AIDS realities as the reproduction of AIDS discourses in Indonesia generates the stigma towards Muslims living with the infection. This paper will be demonstrating the scenario of power, exclusion and resistance within the context of that stigma.
\end{abstract}

Keywords: AIDS, religion, resistence

\section{INTRODUCTION}

Paula Treichler's identification to HIV-AIDS as an = epidemic of signification" has highlighted multiple approaches that we may use to understand the epidemic (Treichler, 1999). We can explore our understanding of AIDS from the proximal level of explanation to the distal level of discussion; from the broader aspects of AIDS in its global context to the particularities and distinctiveness in its specific territories.

This paper can be identified as an AIDS anti-stigma related project, which orients its query to the particular problem of social stigma based on religion in Indonesia. The Indonesian context is important here; as a country that adopts religion as its national belonging" (Bowen, 2003; Boellstroff, 2005) Indonesia challenges our views to question how religion should be involved in the discussion of AIDS.

Particularly in Indonesia, the stigmatization toward people living with HIV-AIDS (PLWHA) is not based only on a misunderstanding about the nature of the disease; the stigma is also rooted epistemologically in the way Indonesian society construes HIV- AIDS according to their religion and belief. In this regard, the stigma around HIV-AIDS differs, from the classical categories of stigma as the abomination of body 
to the blemishes of individual characters (Goffman, 1963). Therefore, religious based stigma should be one of _significant issues' for the discussion of AIDS in this country.

Islam as the religion of the majority in Indonesian society ${ }^{1}$ and the Islamic ethos' that increasingly predominates in the country's popular culture (Boellstroff, 2005) has continuously confirmed about a =common interpretation" of AIDS which considers the disease' as merely a religious moral issue or a behavior related problem. Indeed, HIV- AIDS is perceived by a majority of Indonesian Muslims, as a form of divine retribution, family disgrace, homosexual punishment, or God's heavenly chastisement.

These identifications are even clearer given the findings of my prior investigation on Islamic legal decrees concerning HIV-AIDS, issued by Islamic authorities in Indonesia. ${ }^{2}$ I found that while-in general - these decrees (fatwa) tended to exclude PLWHA from the territory of religious piety', they also constituted a form of power, oppression and marginalization toward PLWHA. They place these individuals in a specific category of _others'.

This paper is then intended to first address a question of how these Islamic authorities construct their power by placing HIV-positive Muslim and non HIV-positive Muslim in such an organized and systemic order, together with a set of rules. It will, therefore-explain how these authorities have attempted to control PLWHA by imposing _rules related to their way of behaving, their understanding of HIV-status and their self- conduct in relation with others. Second, this paper is to report on a preliminary investigation about the reactions of PLWHA toward the fatwa by questioning whether they can accept these fatwa. If they accept the provisions of these decrees, how do they reconcile and adjust their status of being PLWHA to the judgments of these authorities? If they do not accept, how do they react and resist? All in all, this paper will present a scenario of power, exclusion and resistance associated with the phenomena of HIV-AIDS and its religious-based stigma in Indonesia.

${ }^{1}$ In 2000, there were around 177.528.772 Muslims from 201.241.999 of the total population. (Suryadinata: 2003), pp. 101-104

${ }^{2}$ I have investigated the Indonesian Islamic legal decrees on HIV-AIDS in my previous thesis titled Islamic Responses to HIV-AIDS; A Comparative Study on Malik Badri, Farid Esack and Indonesian Muslim Responses (CRCS-UGM 2006) 


\section{DISCUSSION}

\section{Islamic responses to HIV-AIDS and PLWHA in Indonesia; a Construction of power, exclusion and the issue of incommensurability}

My investigation on the situation of HIV-AIDS and Islam" in Indonesia has been arrived to the conclusion that Islamic legal responses to the pandemic have reflected about religious moral judgment ${ }^{3}$ and have helped to produce stigmatization toward HIV- AIDS and the people living with it. The Islamic legal responses which I have identified are issued by three biggest Islamic authorities in Indonesia; which are NU (Nahdlatul Ulama), Muhammadiyah and MUI (the Council of Indonesian Ulama).

NU and Muhammadiyah are the most influential mass-based organizations which have more than 70 million members officially. ${ }^{4} \mathrm{NU}$ is representative of traditional Islam, while Muhammadiyah is representative of ${ }_{=}$modernist Islam. ${ }^{5}$ These two organizations are generally viewed as politically moderate, while MUI as an institution that has been recognized by Indonesian government as the representative of Muslim voices across Indonesia has taken a very conservative turn recently.

The three are authoritative since each of them produces their decrees (fatwa) to be followed by their fellow Muslims. Especially MUI, it has a direct access to the governmental power in order to support their decree. ${ }^{6}$ However, Individual Muslims are not band by fatwa and fatwa do not have an authority of state law.

According to the fatwa of NU, AIDS is simply analogous with leprosy since both are infectious diseases which bring shame and disgrace to family. ${ }^{7} \mathrm{NU}$ even views that person living with HIV-AIDS can marry but their marriage status according to the Islamic law is Makruh

${ }^{3}$ Ibid.

${ }^{4}$ As the organizations have claimed, Muhammadiyah has around thirty million followers whilst $\mathrm{NU}$ has around fourty million members. http://www.watsoninstitute.org/bjwa/archive/9.1/Indonesia/Federspiel.pdf (last access July3rd 2008

${ }^{5}$ Ibid.

${ }^{6}$ The recent case of Indonesian governmental banning of the sect Ahmadiyah" based on MUI fatwa is the best example of this power relation

${ }^{7} \mathrm{NU}$ quotes the hadits (prophet saying) that says "Run away from a person who has leprosy as you run away from a lion” look (Sahal Mahfudz, 2004). 539 
(allowed, but not preferred). Muhammadiyah, on the other hand, has published a collection of Friday sermons (kumpulan khotbah Jum"at) on combating AIDS in Indonesia. ${ }^{8}$ However, the massage of the sermons is about to attribute AIDS to God's punishment; some of the sermons call PLWHA to repent from their sins and return to faith, while some other often quote the story of Sodom and Gomorra, not to mention commenting that AIDS is God's penalty for homosexuals. ${ }^{9}$

Similar to NU and Muhammadiyah, AIDS as the incurable sexually transmitted disease appears to MUI as God's retribution for the human crisis of morality. In order to address their fatwa, MUI begin with a certain Qur'anic verse about God's affliction and punishment (Qs: al-Anfal: 25) and recommends certain rules', after categorizing people into three groups; (1) HIVpositive individuals, (2) people living with high-risk behaviors and (3) Indonesian society in general. ${ }^{10}$

For the HIV-positive individuals, MUI recommended that single people must keep being abstinent from sex at all times, while married couple must, ${ }^{11}$ inform their positive status to their spouse and use condoms during their emergency' sex. ${ }^{12}$ For the people living with high risk behaviors, MUI recommended them to

${ }^{8}$ Tabrani Syabirin, Menghindari AIDS; Kumpulan Khutbah Jumat, (USAIDYASA-PP. Muhammadiyah: Jakarta, 2005).

${ }^{9}$ I should say that at although the fatwa of NU and Muhammadiyah sound discriminative, at the parxis level Fatayat (NU women youth council) and Aisyiah (Muhammadiyah women youth council) have recently done many actions together with KPA (komisi penanggulangan AIDS). Infact, Fatayat and Aisyiah are to some extent autonomous

${ }^{10}$ According to the redaction of fatwa, the fatwa consists of six points which are (a) preamble [Mukaddimah] (b) Tadzkirah Bandung (c) The system of spreading AIDS and information about HIV/ AIDS to people (d) the role of Ulama in HIV-AIDS prevention (e) plan of actions (f) conclusion. http://www.theceli.com/dokumen/produk/lain/muiaids.htm (last access July3rd 2008)

${ }^{11}$ The stress of the word _must" is translated from the original version =wajib. According to Islamic tradition, the word =Wajib' has a religious tone which indicate about control and force

${ }^{12}$ Translated from Indonesian version "Bagi pasangan suami isteri dalam keadaan darurat agar mengenakan kondom dan alat perlindungan lain". Since a married couple supposed to engage in a sexual relation, I question what did MUI mean by the term _emergency' here? 
check their HIV status (especially before they get married) ${ }^{13}$ and for a spouse they have to use condoms ${ }^{14}$ In regard to Indoesian citizen in general, MUI reccomended them to maintain morality, return to faith, increase their piety and avoid sins and bad behaviors.

\section{AIDS and Islam; Morality, Power and the Structure of Piety}

Having observed the response of Islamic authorities in Indonesia, we can say that defining AIDS as problems of behavior and individual morality is the common response of Muslims to the pandemic. This model of response has found its justification especially after the book of Malik Badri a Sudanese Muslim thinker titled AIDS Crisis; a Natural Product of Modernity"s Sexual Revolution (2000), although this book has not been widely influential in Indonesia. ${ }^{15}$

The book represents firstly an occidentalist approach $^{16}$ to the pandemic, since AIDS is framed by the author to be a product of Western modernity and Western - Sexual revolution'. It is clear from the book, that AIDS is mainly attributed to human sexual _errors especially homosexuality, in order to explicitly confirm that AIDS is the punishment of God (Badri, 2000). Secondly, the book also stands for the notion that Islam is the solution for all human problems, including AIDS. In that sense, the massage of the book

${ }^{13}$ This is interesting because this suggests that MUI admits that people have sex before marriage and outside marriage. However, MUI agreed to promote condoms only for married couple.

14 A statement by KH Hasan Basri, the chairman of MUI, was quoted by AFP (August, 4, 1995) as saying that MUI opposes campaigns which advocate the use of condoms to prevent the spread of the HIV?AIDS. He describes this as an open invitation to promiscuity. (See Malik Badri, 2000). 283.

15 As the book was firstly copyrighted in 1997, it was virtually recognized as the first full book on AIDS and Islam, which was given the Award of the best contribution to Islamic medicine for the year 2000 by a trans-national organization on Islamic medical projects, IMA (Islamic Medical Association)

${ }^{16}$ The _Occidentalism" may be identified through (a) War against the West (b). Rejecting _Mind of the West' (c). Expressing the enemy in the context of the _Wrath of God'. (Ian Buruma \& Avishai Marghalit, 2004) 
emphasizes on Islamic morality and Islamic rituals ${ }^{17}$ as the way to combat AIDS. Indeed, Islam is regarded by the author as a complete package of moral conducts to protect Islamic community (Ummah) from any Western contamination. ${ }^{18}$

It seems clear to me, that Indonesian Muslim's responses to the pandemic derived from such a construction. The image of AIDS and PLWHA as attributed to dirty behaviors is created to oppose the image of Islamic behaviors which supposed to bepious, pure and hygienic. Only through this =opposition" we can simply see the exclusion of people who are infected from the territory of piety. In fact, the elimination of lepers in medieval Europe from the church colony (Allen, 2000) seems to be an exact example for this exclusion process. Moreover, NU themselves have explicitly pointed out beforehand that AIDS is analogous to leprosy.

If we see through the moral narrative of AIDS, we will find how the moral perspective it self enforces spower" and scontrol. The contribution of Emile Durkheim to the notion of morality is still highly influential to be used in this context. According to Durkheim, morality is to limit the behavior of individuals to the expectation of the wi der society (Durkheim, 1973b). The purpose of morality is indeed (a) to determine conduct (b) to fix conduct and (c) to eliminate individual arbitrariness (Durkheim 1973b, Shaun Best, 2003).

In reality, by imposing _morality discourse ${ }^{6}$ in the context of AIDS, the Indonesian Islamic authorities have provided rules that prescribe such ways of behaving, so PLWHA will behave according to the rules. In fact they will behave not because some innate force is at work, or because they like to behave in that particular way but because they are subject to regulating moral authority. Here we can see that certainly morality is characterized by its regularity, so irregular behaviors are then regarded as incomplete morality (Durkheim, 1973b).

If we analyze deeper the responses of Dr. Malik Badri as well as the three Islamic institutions in Indonesia, it will be clearer that all have

${ }^{17}$ Badri's view on Islamic rituals as the Islamic way of AIDS prevention can be read at (Badri, 2000.214-221.

${ }^{18}$ From the book, Badri clearly confirms the thesis of Samuel P. Huntington on The Clash of Civilization [1993] (See Badri, 2000), 259-278. 
depicted about a scenario of power and exclusion which can be seen through the making of structure and order. In fact, through the fatwa we have seen how MUI has created _structure and justified about the order of things; that is clear when they classified people into three categories as I have mentioned. In that matter, the order of things is identified by Michael Foucault as the nature of systems of classification (Foucault, 1969a). In fact, according to Durkheim, any system of classification is actually based on a conscience collective (Durkheim and Mauss, 1963a).

Conscience collective is the expectations of individuals that they make when they interact with each other. These expectations come together to form a normative order' which is over and above the individual. Once the conscience collective is established, it exercises a constraint upon people which can inhibit future change within or between the categories (Durkheim and Mauss, 1963a). We can say here that actually this constraint ${ }^{\prime}$ as mentioned by Durkheim is very clear as it is then translated into statements and rules, or according to Foucault, the term is called _a discourse" (Foucault, 1972b).

A discourse, according to Foucault is a body of statements that is both organized and systematic and is in the form of asset of rules (Foucault, 1972b). Discourse is a system of representation that regulates meaning so that certain ways of thinking, speaking and behaving become natural (Foucault, 1972b). it is important to note that discourse for Foucault involves history ${ }^{19}$ and the central concept in the history of any discourse was the will to power" (Foucault, 1972b)

Having understood these theorizations of power, morality, and discourse we can see that actually the episteme of Islamic morality" held by Dr. Malik Badri as well as by the three Islamic institutions have generated the order of discourse. In fact, these fatwa are created to inform people on how they should construct their view about the world, particularly about AIDS and people living with it. In such a way, the order of discourse allows them to

\footnotetext{
${ }^{19}$ What Foucault means by history is that based on problem centered history not period centered. This history is also called _archeology“ (1972). 130
} 
allocate people within a network of categories and describe them as types.

Our picture of _power' is even clearer when we see the fatwa, which tell people about how a person is trained into certain ways of behaving, understanding his own status and how the way a person must relate to others are actually forms of discipline of the body (Foucault, 1977c). Indeed, the process of power and exclusion in the context of the fatwa can be seen through the process of classifying individuals, dividing practices, and understanding one-self (Foucault, 1977c).

\section{Exclusion and Political \\ Religious Piety}

As we have found that the attitude of othering PLWHA is parallel ed to the attitude of =othering homosexuals, we have observed that Islamic piety in the context of AIDS is established by keeping out the dirty behavioral disease' called HIV-AIDS from its territory. Piety is seen as the definition of goodness and cleanness.

Malik Badri as well as the Indonesian Islamic authorities, have arrived upon the identification of AIDS as a mainly homosexuality related concern. In many places, Badri's homophobic views are even translated into statements that homosexuality is indeed the main cause of AIDS crisis' (Badri, 2000). We found such identification also when we read the sermons of Muhammadiyah, which recall the story of Sodom and Gomorra to be used in the context of HIV-AIDS prevention program (Syabirin, 2005). Here we understand the process of exclusion; that the piety is actually _political, since the definition of the political has been developed to indicate more broadly about the power to declare a state of emergency (Turner, 2008). The _political does not only cover _politics“ that involve the humdrum activities of political parties, elections and lobby groups etc. (Turner, 2008). But, the political also include activities which place sovereignty at the core of any inquiry. When Aristotle said that man is _political animal, he invoked this idea of polis as a form of life in which men could rise above mere nature and construct a city' in which sovereign power could be institutionalized (Turner, 2008). 
Thus, it is not a surprise if we may finally arrive to the conclusion that actually the effort of MUI, NU and Muhammadiyah to institutionalize Islamic morality in the context of AIDS is generated by the =will to power. At this point I should say that Malik Badri's tendency of power is even easier to observe when his views on AIDS are actually marked by his political agenda of Islamization' against =Westernization'. It might not be an exaggeration to assume that such Badri's view on Islamization is generated by his dream of Islam to control over the world (Badri, 2000).

After we understand the piety as _political' we can say further that the piety is also religious; from a perspective that sees _religiosity is =communal. Again, Emile Durkheim's explanation on religion is interesting since in his book Elementary forms of Religious Life [1912] he has attempted to describe religion" not on the basis that religion consisted primarily in holding certain beliefs, rather on the basis that religion consists in ritual activities with respect to sacred objects which affect to the creation of a community" (Durkheim, 2001c). So religion, religious or ${ }_{\underline{1}}$ religiosity are best understood in terms of action" rather than belief" (Durkheim, 2001c). It can be seen through this framework that the construction of Islamic-religious piety through the fatwa on HIV-AIDS has demonstrated in itself a tendency of power by excluding PLWHA from the so called a pious _community. Not only this, but it seems that the whole concept of piety has become hegemonic in Indonesia. So, it is not enough to be religious, but a person now has to be openly pious in order to be viewed as a good person and even as a good citizen. Thus people get trapped in debates about whether they are pious enough or not.

We can see after all how those powerful authorities and the powerful movements of pietisation have contributed to oppress PLWHA by _politically“ pushing them out from the territory of Islamic piety. Again I say that PLWHA in Indonesia are not only marginalized because of the nature of the disease that they suffer, but they are also marginalized because of the _pietisation and moralization' movements such as issued by those Islamic authorities. 
Regardless of the fact that there could be innocent people who are infected, babies or even pious persons, if they stand under the category of PLWHA, MUI and such authorities will still recommend God's forgiveness and massive repentance for all PLWHA. ${ }^{20}$ Indeed, the fatwa have really suggested that all PLWHA have to" return to faith and protect their salvation by living under their construction of Islamic piety. But, even if they do so, can they really be part of the pious community?

\section{Incommensurability; Being HIV-positive and being a pious Muslim}

One of the impacts of the political-religious pietisation by reproducing the interpretation of AIDS as God's punishment, disgrace for family, penalty for homosexuals, etc. is the difficulty to reconcile the fact of an existing =HIV-infected being' with a spious Muslim being' at the same time. Indeed, there has been virtually constructed that there is no context in which a _pious Muslim' and _HIV-positive person" have come together in a reality. It seems like AIDS and Islam in Indonesia has already been constructed by the structure as incommensurable and conflicted worldviews.

Having awareness with an increasing ethnographic emphasis on incommensurability" (Boellstroff, 2005 and Povinelli, 2001), I am interested here to see how those Muslims living with AIDS in Indonesia survive and reconcile their status of being HIV-positive person in the midst of the majority judgments that consider them outside the _pious territory.

Through ethnographic analysis, this paper will partly cover the incommensurability analysis and the resistance analysis to understand the context of people who live with HIVAIDS and how they resist the power, challenge the piety and try to resolve these apparently incommensurate statuses of being HIV positive Muslim and being pious Muslim in Indonesia. This frame of incommensurability and resistance analysis are interesting here, especially when we need to see not only the scenario of power that forces PLWHA to live in the margin of _pious' society,

${ }^{20}$ See The fatwa of MUI

http://www.theceli.com/dokumen/produk/lain/muiaids.htm (last access July3rd) 
but also to understand the reaction of PLWHA themselves to face against this power.

\section{The Reactions of PLWHA; a Process of Resistance}

Having understood the scenario of power and the partiality of the exclusion' behind the body of the fatwa, we will reverse our direction to see the next episode of the scenario; when PLWHA in Indonesia take their turn to respond to these fatwa and react to the judgments of Islamic authorities. We need to know the reactions of PLWHA toward the fatwa because indeed PLWHA in Indonesia have been suffering not only because of their illness, but also because of the continuous stigma and condemnation regarding their behavior and morality.

In fact, like the fatwa, the narrow moral-based responses to the pandemic have actually ignored the reality of PLWHA who are suffering from the disease, not because they are morally guilty. The research of Mary Huang Soo Lee (2003) has been suggesting that there are more than $80 \%$ of HIV-infected woman who are monogamous wives and have never had sex except with their legal husbands. ${ }^{21}$ In addition to that, there are numbers of innocent babies in Indonesia who are reported as HIV infected since they were born. ${ }^{22}$ Now, the question is how to apply the religious moral based response into such realities? Indeed, HIV-AIDS is not simply a problem of people having forgotten their faith or their moral values.

Farid Esack, a South African Muslim thinker has promoted an analysis to see the pandemic not only from the narrow-morality based perspective, but rather from the perspective of liberation theology that chooses to see PLWHA not as sinners, but victims of systemic global injustice (Esack, 2004b). Esack derives his vision on HIV-AIDS from his liberation theology' (Esack, 1997a) ${ }^{23}$ that

${ }^{21}$ Mary Huang Soo Lee, from the Malaysian Daily newspaper, The Sun, from WHO report (1995). Also quoted by Malik Badri (2000), 187

22 As reported by Indonesian ministry of Health, there are 199 Indonesian babies in 2006 who are infected since they were born

${ }^{23}$ Liberation theology according to Esack is one that works toward freeing religion from social, political and religious structures and ideas based on uncritical obedience and the freedom of all people from all forms of injustice and exploitation including those of race, gender, class and religion. Farid Esack, (1997), 83 
struggles toward liberating people who are marginalized by society. $\mathrm{He}$ sees that Islam cannot answer the AIDS crisis merely by a call to return to faith and morality.

In his book Islam, Muslims and AIDS: Between Scorn, Pity and Justice (2006c) Esack argues that poverty, social-economic injustice and gender inequity are the actual problems surrounding the disease. He argues that the dominant economic system that reduces people to commodities, or the social systems that consider black people less than the value of _the white or that reduce women to half of men, all have contributed to a disease such as HIV and AIDS $^{24}$

While Esack have been criticizing the narrow moral perspective in the context of AIDS, he has not elaborated further to go beyond the structure that involves in the making of such a moral perspective. However, in many ways Esack's identification of PLWHA as being the victims, the oppressed and the marginalized has been a breathing space to confirm about oppressions that happen toward them. Here I would say that exactly through the moral perspective and the 'pietisation movement' we can see the scenario of power and marginalization. Thus we may argue that moral-based response in the context of AIDS can be identified as yet, another form of the oppression.

As this research has portrayed about the oppression that happens to PLWHA. I should demonstrate in advance about my findings while I pursue my ethnographic effort in examining their reaction and resistance. In fact, this ethnographic quest is relatively new and merely a continuation. However, it was surprising when at the time I am constructing these preliminary questions, I remembered an article published in an Indonesian daily newspaper, in which I found a woman namely Vivi (22 years old) wearing hijab or Jilbab and telling about her story of living with HIVAIDS. In the story, Vivi told that she was infected with HIV from her husband, Adi. The husband was infected with the virus because he was drug user. She knew that her husband was addicted to injected drugs but she never imagined that HIV would infect her. When she told the story, her husband was already dead and she was living with her infected baby. ${ }^{25}$

\footnotetext{
${ }^{24}$ Ibid.

${ }^{25}$ Mirza Revillia, Optimis Melawan AIDS॥, Harian Seputar Indonesia, no.175/first year of 2005 
Definitely, having read her story and looked at her picture I was wondering about a number of meanings, which suddenly revealed for moments. Firstly, about the Jilbab that is commonly used and understood by Indonesian society to symbolize about „piety of a woman. Secondly, about the article, that is published in a national daily newspaper. Thirdly the story of her being HIV positive and how she expressed her story of being not guilty, all of these meanings should direct on some thing. My query is then to question whether these facts' mean to some degrees resistance'?

\section{Resistance without Protest}

As a sociological term, Resistance“ is defined by many writers differently from acting autonomously in one own interest (Greeg, 1993), active effort to oppose, fight and refuse to cooperate with or submit to...abusive behavior and...control' (Profitt, 1996), engaging in behaviors despite opposition (Carr, 1998) to simply questioning and objecting (Modigliani. et all, 1995).

The term refers usually to social movements or even broader categories of protest (Jasper, 1997). The definitions of the term also expand from issues of social control and social structure to issues of agency (Hollander. et all, 2004). However, there are still a fairly small number of principles according to which continua of social protest might be generated (Scott, 1986b). Being aware with the debate of conceptualizing _resistance (Hollander. et all, 2004) I tend to use a theory of resistance proposed by a political scientist, James Scott who introduced a model of resistance which does not expect any forms of protest or any expression of long-march" or demonstration. In reality, there is a form of resistance which is as what Scott called _every day acts' (Scott, 1985a-1990b).

Viewing Vivi's picture and understanding her story through Scott's perspective of resistance will certainly questions whether such Vivi's published article and her picture may really represent a form of resistance, as Scott have suggested? In fact, if we want to place Vivi's story in the context of Scott's concept of resistance" we may arguably admit that PLWHA's resistance toward the common moral 
response or the fatwa of Indonesian Islamic authorities occur well outside any standard definition of social movements.

I am definitely aware that while many scholars address the issue of intention behind the action, Scott's theory of resistance excuses the difficulty of assessing such intention, if not impossible. It is merely a matter on indication. However he suggests that we can reasonably infer intention from

actions (Scott, 1985). In this context, Vivi herself might not intend to resist by showing up with her Jilbab. Or she actually might have an intention to resist but the _powerful structure of moral judgment may not recognize her resistance and consider her story as nothing to do with the fatwa. However, what the indication suggests is enough to identify her article as a form of resistance, because resistance according to Scott does need neither intention" nor _recognition" (Scott, 1985). Specifically on the jilbab show, I will argue that using Scott's theory of resistance here is even very helpful to understand at least a pattern of resistance against the oppressive moral structure that considers HIV status as incommensurate' with Islamic piety.

In the context of Vivi, It is also arguable to say that =telling a personal story is a kind of ordinary weapons of relatively powerless groups such as PLWHA, because it requires little or no planning, it often represents forms of individual self help and avoids any direct symbolic confrontation with authority or with elite norms. However, the resistance is happening. So how do we know that some thing is resistance? As Scott has said beforehand that we can assume intention from the action (Scott, 1985), we can say that resistance can be seen through its effects and consequences. Indeed, as I believed, Scott has successfully reflected this fact of resistance into his models and typologies of social conflict. Scott himself said It is certainly true that recent social history has been far more attentive to forms of struggle that fall well short of riot and rebellion (Scott, 1986).

\section{A minor piety; another form of resistance}

Vivi's story is merely a pattern that I only used to construct my own framework on this research and begin with my ethnographic exercise. The real preliminary finding of me suggested 
that some Muslims living with AIDS in Indonesia have resisted the structure of Islamic piety" by making what I called a minor piety.

As I have tended to identify the _political-Islamic piety as the _major piety in which $\_$a pious Islam is constructed to be, the term minor piety is to describe the interpretations of _piety which are made by those HIVpositive Muslims themselves, as forms of their resistances toward such „pietisation movement and moral judgmentalism.

In fact, among eight PLWHA ${ }^{26}$ whom I have been interviewed, not all of them are interested in giving meaning to their status. Many of them simply take silence way. Here I should say that Scott has also identified that silence is also _a weapon among the weak' (Scott, 1985). However, all of PLWHA whom I interviewed are _denial ${ }^{276}$ to the fatwa of Islamic authorities in Indonesia when I show them the drafts. In fact, only three of them gave _comments' which I identify them as their interpretation of minor piety.

\section{A woman named Mariati (42 years old) said}

"...,HIV is not a punishment; it is only a „test" from God. We are "positive" only because we are tested by this virus... You see, the person who is examined and then successful is actually the one who deserves to be rewarded and to be labeled as "pious"...not them (MUI etc.)"

Another young person named Hunain' (31 years old) said to simplify narration "I understand my own piety in the way I approach God every nights. You will never experience any piety compared with a pious HIV positive person, because they approach and believe in God as they really believe in his near-coming death."

It might be easier for PLWHA like Vivi, for instance, to resist the powerful pietisation" since she thought that she

${ }^{26}$ I use spersons' because they do not want their names to be mentioned. However I will provide _aliases

${ }^{27}$ Almost all of them said that the fatwa hurts us and has to be revised', but when I question how to revise? In what manner do you want? they simply say I don't know. 
was not doing any guilt behavior" when she contracted AIDS. However, there are still huge numbers of Muslims living with AIDS who still engage risky behaviors but at the same time they cannot accept any moral judgments and any model of Islamic pietisation. For them, they themselves are still pious Muslims no matter what they are doing and no matter how they got the HIV infection. In addition, there are many pious Muslims without HIV who engage in risky behaviors.

A male named Fredy (27 years old) said, Who are they talking about our morality? No matter how did I get this HIV but for me, "a piety" of person is in his heart. Every body can know his/her own piety themselves. People who see us this way may not be more pious than us, they may even worse they said we must tell our HIV-status, To Whom It May Concern. Do they think that is easy?

It seems that the _pietisation or any power behind the fatwa; each represents a structure of ideas and practices that penetrates but does not encompass the lives of its practitioners (Boellstroff, 2005). The major piety' that condemns PLWHA seems confronts individual interpretations of their own status. It seems that through primarily interpretation, those PLWHA inhabit the incommensurate gap between being HIV positive" and Deing pious Muslim' at the same time.

In fact, for the meanings of piety that $I$ am struggling to put them under the term _minor-piety some of them reduce the conception of religious piety into mere spirituality; specifically piety which emphasizes on individual relation to a divine Being; Allah. It seems that through the effort of some HIV-positive Muslims whom I met, they understand that the piety of Islam is not fully as the piety which is understood by MUI, NU or Muhammadiyah. But rather they consider themselves spious with their own understanding and interpretation.

\section{CLOSSING}

While in general, this paper narrates a story about a situation of HIV-AIDS and its religious based stigma in Indonesia, it tells also about an interesting scenario of power, exclusion and resistance within the context of that stigma. The power is demonstrated through the fatwa of Islamic authorities toward AIDS and PLWHA, by analyzing the structure of moral judgmentalism, the discourse of Islamic piety, the 
construction of hegemonic understanding of AIDS, the discipline and order, and the exclusion of PLWHA from the territory of the pious. On the other hand, the resistance of PLWHA toward these Islamic authorities is described through their effort of contesting their own interpretation, understanding-self, telling their stories, creating their own piety and inhabiting the incommensurability of being =HIV positive' and being pious Muslim' at the same time.

Referring back to Paula Treichler who refers to AIDS as an epidemic of signification, what does the case of religious based stigma of AIDS in Indonesia signify about the relation between AIDS and religion more generally? This paper answers that religious-moral based responses and _pietisation movement ${ }^{\prime}$ in the context of AIDS involves normative power that excludes PLWHA from the community of the pious. In regard to this, religious practices, beliefs and interpretations have an important role in the production of stigma toward the PLWHA.

However, through a dynamic process of oppression and resistance, PLWHA as who live in Indonesia may also have an ability to construct forms of piety، that helps not only to make their lives meaningful but also to make them again accepted as part of the pious community. This is a form of resistance but outside the realm of a social movement. Nevertheless, the further question will be; can such forms of individual agency contribute to a broader social change?

\section{References}

\section{Book}

Best Shaun. 2003 A Beginner's Guide to Social Theory, New Delhi: Sage Publication

E.Durkheim, 2001c, The Elementary Forms of Religious Life, Oxford: Oxford University Press.

1973b, Moral Education: A Study in the Theory of The Sociology of Education, trans. E.K. Wilson and H. Schuner. New York: Free Press of Glenco . and M. Mauss, 1963a, Primitive Classsification, trans R. Needham. London: Cohen \& West. 
E. Goffman, 1963, Stigma; Notes on the Management of Spoiled Identity. New York: J. Aronson

Farid Esack, 1997a, Qur"an Liberation and Pluralism; an Islamic Perspective of Inter Religious Solidarity against Oppression. England: One World.

,2004b, HIV, AIDS and ISLAM: Reflection Based on Compassion, Responsibility and Justice. South Africa: Positive Muslims.

2006c, Islam, Muslims and AIDS; Between Scorn, Pity and Justice, South Africa: Positive Muslims.

. 2006d, HIV, AIDS and Islam; An Awareness-Rising Workshop Manual Based on Compassion, Responsibility and Justice. South Africa: Positive Muslims.

Ian Buruma, Avishai Margalit. 2004, Occidentalism, New York-USA: The Penguin Pres,

James C Scott, 1985a, Weapons of the Weaks: Every Day Forms of Peasant Resistance, New Haven, CT: Yale University Press

John $\mathrm{R}$ Bowen. 2003. Islam, Law and Equality in Indonesia; An Anthropology of Public Reasoning. Cambridge: Cambridge University Press.

Leo Suryadinata, Evi N.A. and Aris Ananta, 2003. Penduduk Indonesia; Etnis dan Agama Dalam Era Perubahan Politik. Jakarta: LP3ES

Malik Badri. 2000, AIDS Crisis; A Natural Product of Modernity"s Sexual Revolution Kuala Lumpur-Malaysia: Madeena Book,

Michael Foucault, 1969a, The order of Things; An Archeology of Human Science (1966) Trans. A Sheridan-Smith. Tavistock: London 1972b, The Archeology of Knowledge, Trans. AM. Sheridan Smith. Tavistock: London.

1977c. Discipline and punish: The Birth of the Prison, Trans A Sheridan-Smith. Penguin: London

Nina Gregg, 1993, "'Trying to put first things first'; Negotiating subjectivities in a workplace organizing campaign", (in) Fisher and Davis, Negotiating at the Margins: The Gendered Discourses of Power and Resistance. New Brunswick, NJ: Rutgers University Press.

Peter Lewis Allen, (2000). The Wage of Sin: Sex and Disease, Past and present, London: Chicago Press 
Sahal Mahfudz, [preface], 2004, Solusi Problematika Aktual HUkum Islam; Keputusan Muktamar, MUNAS dan KONBES Nahdlatul Ulama [1926-1999]. Jakarta: LTN-NU dan Diantama.

Thabrani Syabirin, (ed.), 2005, Menghindari AIDS; Kumpulan Khutbah Jumat. Jakarta: USAID-YASA-PP Muhammadiyah

\section{Journal, Magazine}

Andre Modigliani, and Francois Rochat. 1995, "The role of interaction sequences and the timing of resistance in shaping obe- dience and defiance to authority." Journal of Social Issues 51:107-123

C. Lynn Carr, 1998, "Tomboy resistance and conformity: Agency in social psychological gender theory." Gender \& Society 12:528- 553.

Jocelyn A Hollander and Rachel L. Einwohner. 2004, Conceptualizing Resistance, Sociological Forum vol 19, no 4, pp. 533-554

Lee Durmmond, 1997, _Structure and process in the Interpretation of South African Myth: The Arawak Dog Spirit People', American Anthropologist, New Series Vol. 79. no 4, pp. 842-868

Malik Badri, 2002. \|Developing Morally and Psychologically Sound Muslim Youth\|, SALAM Magazine, Malaysia: Austrlian Society of Islamic Psychology and FAMSY.

Michael F Brown, 1996, On Resisting Resistance, American Anthropologist vol. 98 issue 4 pp. 729-735

Tom Boellstroff, 2005, Between Religion and Desire: Being Muslim and Gay in Indonesia, American Anthropologist vol. 107, issue 4 pp 575-585. 
HIV-AIDS AND ISLAM' IN INDONESIA;

POWER NARRATIVES AND RESISTANCE (Syamsu Madyan) 